\title{
Tinjauan Yuridis Tentang Pertimbangan Hukum Penghentian Penyidikan Terhadap Tindak Pidana dan Akibat Hukumnya (Studi Kasus di Polres Kota Bima)
}

\author{
Wayan Resmini' ${ }^{1}$ \& Taufikurrahman ${ }^{2}$ \\ ${ }^{1}$ Pendidikan Pancasila dan Kewarganegaraan, Universitas Muhammadiyah Mataram, wayanresmini@ymail.com \\ ${ }^{2}$ Pendidikan Pancasila dan Kewarganegaraan, Universitas Muhammadiyah Mataram, taufikurahman9@gmail.com
}

\begin{abstract}
INFO ARTIKEL
Riwayat Artikel:

Diterima: 14-

Februari-2019

Disetujui: 26-Maret2019
\end{abstract}

Kata Kunci:
Pertimbangan
Hukum
Penghentian
Penyidikan;
Tindak Pidana;
Akibat Hukum.

\section{A. LATAR BELAKANG}

Penangkapan atau penahanan yang sebetulnya dilakukan dengan tujuan untuk kepentingan pemeriksaan demi tegaknya keadilan dan ketertiban dalam masyarakat, ternyata sering kali dilakukan terhadap orang yang tidak bersalah atau kadang-kadang dilakukan terhadap orang yang tidak bersalah atau kerapkali dilakukan melampaui batas waktu yang telah ditentukan, sehingga tersangka atau terdakwa menderita lahir bathin akibat sikap tindak para aparat penegak

\section{ABSTRAK}

Abstrak: Penahanan dilakukan dengan tujuan untuk kepentingan pemeriksaan, demi keadilan dan ketertiban dalam masyarakat, hal ini dilakukan terhadap orang yang tidak bersalah, sehingga tersangka atau terdakwa menderita lahir bathin akibat sikap tindak para aparat penegak hukum tersebut. Tujuan penelitian yaitu 1) Untuk mengetahui pertimbangan hukum penghentian penyidikan terhadap tindak pidana. 2) Untuk mengetahui akibat hukumnya jika terjadi penghentian penyidikan terhadap tindak pidana di Polres Kota Bima. Metode menggunakan penelitian empiris dengan pendekatan sosiologi hukum. Subjek penelitian yaitu staf di Polres Kota Bima. Metode pengumpulan data menggunakan observasi, wawancara dan dokumentasi. Metode analisis data menggunakan metode analisis interaktif. Hasil penelitian menunjukkan 1). Pertimbangan hukum penghentian penyidikan terhadap tindak pidana di Polres Kota Bima meliputi tidak diperoleh bukti yang cukup, peristiwa yang semula dianggap bukan tindak pidana dan penghentian penyidikan demi penegakkan hukum. Praperadilan dilakukan untuk penegakan hukum dan perlindungan hak asasi korban dalam semua tingkat pemeriksaan perkara pidana. 2) Akibat hukum jika terjadi penghentian penyidikan terhadap tindak pidana meliputi mempermudah penyidik dalam menyelesaikan kasus, sebagai kekuatan alat bukti dan mempercepat proses hukum, serta penyidik akan menilai keterangan terdakwa sebagai suatu keterangan yang mengandung unsur kebenaran dan dapat digunakan sebagai alat bukti. Jadi adanya kekuataan alat bukti yang bisa menghentikan kasus tindak pidana.

\begin{abstract}
The detention was carried out for examination, for the sake of justice and order in the community, this was done against innocent people so that the suspect or defendant suffered physical birth due to the attitude of the law enforcement officers. The research objectives are 1) To find out the legal considerations for terminating investigations into criminal acts. 2) To find out the legal consequences if there is a cessation of an investigation into crime in the Bima City Police Station. The method uses empirical research with a legal sociology approach. The research subjects were staff at the Bima City Police Station. Methods of collecting data using observation, interviews, and documentation. Data analysis method uses interactive analysis methods. The results of the study show 1). Legal considerations for terminating investigations into crimes in Bima City Police Station include insufficient evidence, events that were not considered criminal offenses and termination of studies for law enforcement. Pretrial is carried out for law enforcement and protection of victims' basic rights at all levels of criminal case checks. 2) The legal consequences of the termination of an investigation into a criminal offense include making it easier for the investigator to settle the case, as a force of evidence and expedite the legal process, and the investigator will assess the defendant's statement as information containing proof and can be used as evidence. So there is the power of evidence that can stop criminal cases.
\end{abstract}

hukum tersebut. Sudah tentu ini merupakan pelanggaran terhadap hak asasi manusia.

Untuk menjamin perlindungan hak asasi manusia dan agar para aparat penegak hukum menjalankan tugasnya secara konsekuen, maka KUHAP membentuk suatu lembaga baru yang dinamakan praperadilan. Adapun tujuannya adalah sebagai lembaga yang berwenang untuk melakukan pengawasan dan aparat penegak hukum men-jalankan tugas dalam peradilan pidana. Lembaga praperadilan merupakan wewenang 
baru yang diberikan oleh KUHAP pada Pengadilan Negeri, adalah merupakan kewenangan Pengadilan Negeri untuk melakukan pengawasan horizontal terhadap segala tindakan yang berkaitan dengan proses penyidikan dan proses penuntutan perkara pidana yang dilakukan oleh pejabat-pejabat dalam tahap pemeriksaan penyidikan dan atau penuntutan. Hal ini diuraikan dalam tulisan di bawah ini.

Hak warga negara inilah yang utama dibandingkan dengan hak politik dan hak sosial, sebab apabila hal ini benar-benar dimiliki oleh para warga negara dan dipertahankan oleh pengadilan, barulah hak politik dan hak sosial mempunyai arti. Pengertian HAM itu sendiri adalah inhaerent dipunyai oleh setiap manusia makhluk Tuhan dan merupakan anugerah Tuhan kepada semua hamba-Nya tanpa pandang bulu. Hak asasi manusia adalah demikian melekat pada sifat manusia, sehingga tanpa hak-hak itu tidak mungkin mempunyai martabat sebagai manusia. Karena itu pula harus dinyatakan bahwa HAM itu tidak dapat dicabut dan tidak boleh dilanggar, sebagaimana hal ini telah dijamin oleh sila kedua dari Pancasila yaitu sila Kemanusiaan Yang Adil dan Beradab dengan disemangati oleh sila-sila lainnya dari Pancasila. Karakteristik inilah yang membedakan Hak asasi manusia dari hak-hak lainnya yang diberikan oleh peraturan perundang-undangan [1].

Dalam praktek peradilan, sering kali ditemui beberapa permasalahan yang berkaitan dengan hukum acara pemeriksaan yang harus diterapkan oleh hakim untuk menerima, memeriksa dan memberikan putusan atas permintaan praperadilan yang diajukan kepadanya mengingat KUHAP sendiri tidak secara tegas menyebutkan hukum acara mana yang harus dipergunakan oleh hakim dalam pemeriksaan di persidangan. Dalam hal pemanggilan para pihak, misalnya Mahkamah Agung menegaskan dipergunakan ketentuan KUHAP, sedangkan dalam praktik sudah semua pemanggilan dilakukan oleh Jurusita. Demikian pula mengenai hukum acara di dalam persidangan, oleh karena para pihak yang tersangkut praperadilan bukannya penuntut umum dan terdakwa atau penggugat dan tergugat, sebagaimana dalam acara pemeriksa-an pidana maupun perdata, maka terdapat kecenderungan pemeriksaan praperadilan bersifat quasi penggugat dan quasi tergugat [2].

Proses penyidikan, penuntut dan pemidanaan dianggap sebagai tidak mempunyai permasalahan hukum. Dalam keadaan ini begitu mudah seorang tersangka, seorang warga negara seperti, tanpa melalui prosedur hukum yang adil berubah status hukumnya menjadi tersangka atau terdakwa dalam kasus tindak pidana. Berbagai kasus di Indonesia terkait dengan penghentikan penyidikan terhadap tindak pidana akibat kurangnya alat bukti yang cukup, misalnya kasus penghentian penyidikan pada perkara Chandra dan Bibit tentang penyalahgunaan wewenang, dilakukan oleh kejaksaan dengan mengeluarkan Suran Ketetapan
Penghentian Penuntutan (SKP2) atas permintaan Presiden yang meminta penyelesaian kasus ini dilakukan diluar pengadilan (Out of Court Settlemet). Padahal apabila dilihat dari kasusnya itu sendiri, maka sebenarnya kasus Chandra dan Bibit ini merupakan kasus biasa, namun penangananya sangatlah luar biasa karena melibatkan semua elemen yang ada baik itu organisasi mahasiswa, organisasi masayarakat, LSM, media massa baik cetak maupun elektronik yang membentuk opini masyarakat. Demikian juga di NTB, kasus penghentian penyidikan juga pernah dilakukan oleh pihak polisi, khususnya pada kasus KDRT yang dilakukan oleh Husni terhadap Aminah warga Kota Mataram. Dimana pada kasus tersebut, Aminah sebagai korban telah melaporkan ke pihak polisi dan berkas penyidikan telah siap. Akan tetapi Husni sebagai pelaku dan Aminah sebagai korban telah melakukan perdamaian di luar polisi. Oleh karena pertimbangan keluarga yaitu anak-anak pasangan Husni dan Aminah, maka pihak polisi menghentikan penyelidikannya.

Sementara berdasarkan hasil observasi awal di Polres Kota Bima berbagai kasus yang diberhentikan penyelidikannya oleh pihak polisi. Salah satu penyebabnya adalah maraknya upaya damai di luar penyidik yang dilakukan ketika timbul perkara, para pihak cenderung mengambil jalur perdamaian karena dianggap lebih efektif dan efesien ketimbang melalui proses peradilan yang menyita waktu, materi, dan tenaga. Selain itu, penelitian sebelumnya menjelaskan bahwa penghentian penyidikan perkara yang dilakukan oleh Termohon dengan alasan tidak cukup bukti atas delik dalam Pasal 149 ayat (1) KUHP, tidak sesuai dengan peraturan perundang-undangan dalam Pasal 109 ayat (2) KUHAP), sehingga berdasarkan hal demikian, Penghentian penyidikan yang dilakukan termohon, menurut pengadilan tidak berdasar hukum[3]. Lainnya menjelaskan bahwa penyelidik-penyidik sebagai anggota Kepolisian, pada prinsipnya memiliki kewenangan diskresioner. Adanya prosedur operasi baku berkaitan dengan proses penyidikan tidak serta merta meniadakan kewenangan diskresioner yang ada pada penyidik kepolisian. Berhadapan dengan dugaan adanya tindak pidana, mereka sudah sepatutnya memiliki dan menikmati kebebasan kebijaksanaan (beleidsvrijheid) dan kebebasan penilaian (beordelingsvrijheid), terutama ketika berhadapan dengan norma-norma yang tidak selamanya jelas. Ketidakjelasan atau kekaburan ini muncul ketika mereka harus menerjemahkan kapan dan bilamana ada alasan kurang bukti dan/ atau bukan perkara pidana untuk membenarkan penerbitan $\mathrm{SP}_{3}$ [4].

Terkait dengan penghentian penyidikan tindak pidana ada beberapa pertimbangan yang harus diketahui oleh seorang hakim yakni 1) Wewenang Jaksa sebagai penuntut umum yaitu meneliti berkas perkara apakah berkas perkara tersangka dapat dilimpahkan sampai kepada pemeriksaan di sidang pegadilan ataukah tidak, 
atas dasar alasan yang benar-benar penting menurut hukum, guna kepentingan pemeriksaan atas penuntutan. 2) Alasan penghetian penuntutan seperti yang disebutkan dalam Pasal 140 ayat (2) huruf a KUHAP, alasan penghetian penuntutan adalah: karena tidak cukup bukti, peristiwa tersebut ternyata bukan merupakan tindak pidana, perkara ditutup demi hukum. Namun demikian alasan tersebut bisa digunakan untuk tidak jadi menuntut oleh penuntut umum seperti yang ditentukan dalam pasal 46 ayat (1) huruf b KUHAP. Berarti perkara tersebut belum sampai dilimpahkan ke pengadilan. Jadi apabila berkas perkara dipaksakan untuk dilimpahkan ke sidang pengadilan, sudah barang tentu hakim akan memutuskan perkara tersebut yaitu dalam bentuk putusan bebas (Vrijpraak) atau putusan lepas dari segala Tuntutan Hukum (onslag van rechtvervolging). Jadi apabila perkara tersebut diteruskan dikemudian hari dan ternyata terdapat bukti baru, bukti yang sangat beralasan untuk dapat diproses kembali dan dilimpahkan ke sidang pengadilan[5].

Berdasarkan uraian tersebut di atas penulis tertarik membahas tinjauan yuridis tentang pertimbangan hukum penghentian penyidikan terhadap tindak pidana dan akibat hukumnya (studi kasus di Polres Kota Bima)". Tujuan penelitian ini adalah untuk mengetahui pertimbangan hukum penghentian penyidikan terhadap tindak pidana di Polres Kota Bima, dan untuk mengetahui akibat hukumnya jika terjadi penghentian penyidikan terhadap tindak pidana di Polres Kota Bima.

\section{B. METODE PENELITIAN}

1. Metode Penelitian yang Digunakan

Metode penelitian yang digunakan adalah jenis penelitian hukum empiris. Metode penelitian hukum empiris adalah jenis penelitian dalam mendekati masalah yang diteliti dengan sifat hukum yang nyata atau sesuai dengan kenyataan yang hidup dalam masyarakat. Jadi metode penelitian hukum empiris harus dilakukan di lapangan, dengan menggunakan metode dan teknik penelitian lapangan. Peneliti harus mengadakan kunjungan kepada subjek dan berkomunikasi dengan para irformen [6].

Ada dua pendekatan penelitian empiris yaitu yuridis empiris yakni jenis penelitian dalam mendekati masalah yang diteliti dengan sifat hukum yang nyata atau sesuai dengan kenyataan yang hidup dalam masyarakat, dan yuridis normatif yakni suatu proses untuk menemukan suatu aturan hukum, prinsip-prinsip hukum, maupun doktrin-doktrin hukum untuk menjawab permasalahan hukum yang terjadi [6]

Dalam penelitian ini pendekatan yang digunakan pendekatan sosilogis hukum yang merupakan suatu pendekatan yang mempelajari keteraturan dan berfungsinya hukum. Oleh karena itu, metode penelitian yang digunakan adalah metode penelitian empiris dengan pendekatan sosilogis hukum tentang tinjauan yuridis tentang pertimbangan hukum penghentian penyidikan terhadap tindak pidana dan akibat hukumnya.
2. Subjek Penelitian

Subjek penelitian adalah sekumpulan kasus yang perlu memenuhi syarat-syarat tertentu yang berkaitan dengan masalah penelitian [7]. Ahli lain mengemukakan bahwa subjek penelitian adalah sejumlah kasus yang memenuhi seperangkat kriteria [6]. Dalam penelitian yuridis empiris tidak menggunakan populasi, karena penelitian kualitatif berangkat dari kasus tertentu yang ada pada situasi sosial tertentu dan hasil kajiannya tidak akan diberlakukan ke populasi, tetapi di tranferkan ketempat lain pada situasi sosial yang memiliki kesamaan dengan situasi sosial pada kasusu yang di pelajari.

Jadi subjek penelitian adalah orang yang paling mengetahui tentang tinjauan yuridis pertimbangan hukum penghentian penyidikan terhadap tindak pidana dan akibat hukumnya. Oleh karena itu yang menjadi informan dalam penelitian ini adalah staf di Polres Kota Bima.

\section{Teknik Pengumpulan Data}

Teknik pengumpulan data adalah cara yang digunakan oleh peneliti untuk mengumpulkan data, dalam hal ini adalah proses diperolehnya data dari sumber data, sumber data yang dimaksud berasal dari subjek penelitian [6]. Dalam penelitian ini, data yang dikumpulkan menggunakan metode sebagai berikut:

a. Metode Observasi

Observasi adalah pengamatan kepada tingkah laku pada suatu situasi tertentu[7]. Pendapat lain mengemukakan bahwa "observasi adalah alat untuk mengumpulkan data berupa tingkah laku tertentu" [6]. Selanjutnya menurut [7], jenis-jenis observasi meliputi observasi terbuka, yaitu melakukan observasi secara sistematik dengan memberitahu dan meminta izin terlebih dahulu pada subjek yang diamati, sedangkan observasi tertutup yaitu melakukan observasi tanpa meminta izin terlebih dahulu pada subjek yang diamati.

Dari kedua pendapat tersebut, maka metode observasi yang digunakan dalam penelitian ini adalah metode observasi terbuka untuk mengumpulkan data dengan cara mengamati tentang tinjauan yuridis pertimbangan hukum penghentian penyidikan terhadap tindak pidana dan akibat hukumnya.

b. Metode Wawancara

Metode wawancara adalah sebuah dialog yang dilakukan oleh pewawancara [7]. Pendapat lain mengatakan bahwa metode wawancara adalah suatu teknik pengumpulan data yang dilakuka dengan cara tanya jawab antara penanya atau pewawancara dengan responden/penjawab" [8].

Dari kedua pendapat ahli di atas, dapat disimpulkan bahwa metode wawancara adalah teknik pengumpulan data dengan cara tanya jawab secara langsung, yang dilakukan oleh pewawancara dengan responden untuk memperoleh informasi yang diinginkan.

Jenis wawancara dibedakan menjadi wawancara terstruktur dan tidak terstruktur. Dikatakan terstuktur 
apabila pertanyaan yang akan diajukan telah tersusun dalam suatu catatan secara jelas dan terinci. Dikatakan tidak terstruktur apabila pertanyaan yang akan diajukan tidak disusun secara jelas dan terinci [8].

Bentuk wawancara yang digunakan yaitu wawancara tidak terstruktur dimana saat wawancara pertanyaan yang akan diajukan tidak disusun secara jelas dan terinci. Selain itu bentuk wawancara ini juga memberikan kebebasan kepada peneliti dalam mengatur kata-kata saat menge-mukakan pendapatnya sehingga tidak berkesan resmi. Peneliti bisa menyiapkan ramburambu pertanyaan yang diajukan dan dapat dikembangkan saat wawancara berlangsung. Saat wawancara peneliti haruslah menghindari perkataan yang kurang terkesan mengurangi informan serta peneliti juga harus pandai mengarahkan informan jika terdapat jawaban yang kurang jelas.

Alasan menggunakan metode wawancara adalah agar peneliti dengan mudah medapatkan informasi terhadap apa yang menjadi permasalah-an yang akan diteliti dan bisa menambah wawasan, pengalaman yang lebih luas, serta peneliti juga dapat menggali soal-soal penting yang belum terpikirkan dalam rencana penelitian tentang tinjauan yuridis pertimbangan hukum penghentian penyidikan terhadap tindak pidana dan akibat hukumnya.

\section{c. Metode Dokumentasi}

Metode dokumentasi yaitu mencari data mengenai hal-hal atau variabel yang berupa catatan, transkrip, buku, surat kabar, majalah, prasasti, notulen raport, lager agenda dan sebagainya[7]. Atas dasar pendapat para ahli tersebut maka yang dimaksud dengan metode dokumentasi adalah "Bentuk catatan mengenai siswa yang telah dicatat, dalam kumpulan tentang keadaan siswa seperti buku induk, rapor, buku pribadi dan sejenisnya". Metode dokumentasi dalam penelitian ini yaitu data tentang profil Polres Kota Bima.

\section{Teknik Analisi Data}

Analisis data dalam penelitian hukum empiris merupakan kegiatan dalam penelitian yang berupa kajian atau telaah terhadap hasil penelitian, pengolahan data yang dibantu dengan teori-teori yang telah didapatkan sebelumya [9].

Analisis data dalam penelitian hukum memiliki sifat-sifat seperti deskriptif, evaluatif dan prespektif. Sifat-sifat analisis ini akan diuaraiakn sebagai berikut:[10]

\section{a. Deskriptif}

Sifat analis deskriptif adalah bahwa peneliti dalam menganalisis berkeinginan untuk memberikan gambaran atau pemaparan atas subjek dan objek penelitian sebagaimana hasil penelitian yang dilakukanya.

\section{b. Evaluatif}

Dalam analisis data yang bersifat evaluatif ini peneliti memberikan justifikasi atas hasil penelitian. Peneliti akan memberikan penelaian dari hasil penelitian, apakah hipotesis dari teori hukum yang diajukan diterima atau ditolak.

c. Prespektif

Sifat analisis ini dimaksudkan untuk memberikan argumentasi atas hasil penelitian yang telah dilakukanya. Argumentasi di sini dilakukan oleh peneliti untuk memberikan prespektif atau penelaian mengenai benar atau salah menurut hukum terhadap fakta atau peristiwa hukum dari hasil penelitian tersebut.

\section{HASIL PENELITIAN}

\section{Pertimbangan Hukum Penghentian Penyidikan Terhadap Tindak Pidana di Polres Kota Bima}

Penyidikan sebagai serangkaian tindakan yang dilakukan pejabat penyidik sesuai dengan cara yang diatur dalam undang-undang untuk mencari serta mengumpulkan bukti, dan dengan bukti itu membuat atau menjadi terang tindak pidana yang terjadi serta sekaligus menemukan tersangkanya atau pelaku tindak pidananya. Hal tersebut diungkapkan oleh selaku Pelaksana Tugas Pokok berikut ini.

"Penyidikan adalah merupakan tindakan untuk mencari serta mengumpulkan bukti supaya tindak pidana yang ditemukan dapat menjadi terang, serta agar dapat menemukan dan menentukan pelakunya. Sedangkan pihak penyidik adalah pejabat Polri atau pejabat pegawai negeri tertentu yang diberi wewenang khusus oleh undang-undang untuk melakukan tindakan penyidikan "(Bapak AKBP Munawar, Wawancara 1 Desember 2015).

Penyidik yaitu orang yang melakukan penyidikan yang terdiri dari pejabat seperti yang dijelaskan pada pasal 1 butir 1 [12]. Kemudian dipertegas dan diperinci lagi dalam pasal 6 [12], akan tetapi di samping apa yang diatur dalam pasal 1 butir 1 dan pasal 6 tersebut terdapat lagi pasal 10 yang mengatur tentang adanya penyidik pembantu di samping penyidik.

Pejabat polisi yang dapat diangkat sebagai pejabat penyidik penuh, harus memenuhi syarat kepangkatan dan pengangkatan. Hal tersebut diungkapkan oleh Inspektur Dua Polisi berikut ini.

1) Sekurang-kurangnya berpangkat Pembantu Letnan Dua Polisi (setara dengan Inspektur Dua Polisi);

2) Atau yang berpangkat bintara (setara brigadir) di bawah Pembantu Letnan Dua apabila dalam suatu sektor kepolisian tidak ada pejabat penyidik yang berpangkat Pembantu Letnan Dua;

3) Ditunjuk dan diangkat oleh Kepala Kepolisian RI (Bapak AKBP Rian Hidayat, Wawancara 1 Desember 2015).

Syarat kepangkatan dan pengangkatan pejabat polisi menjadi pejabat penyidik. Prinsipnya syarat kepangkatan pejabat penyidik sekurang-kurangnya berpangkat Pembantu Letnan Dua, namun mengingat kurangnya tenaga personel yang belum memadai terutama di daerah-daerah atau di kantor sektor kepolisian, Peraturan Pemerintah memperkenankan 
jabatan penyidik dipangku oleh seorang anggota kepolisian yang berpangkat bintara. Kepangkatan yang serupa ini memang tidak serasa jika ditinjau dari sudut keseimbangan kepangkatan penuntut umum maupun hakim yang bertugas di Pengadilan Negeri. Apalagi dari segi kemampuan pengetahuan hukum seorang bintara kurang dapat dipertanggungjawabkan segi kemampuan dan pengalaman. Itu sebabnya sering dijumpai penyidikan yang tidak memadai dan tidak terarah.

Pejabat polisi yang dapat diangkat sebagai penyidik pembantu diatur dalam pasal 3 [12]. Menurut ketentuan ini, syarat kepengakatan untuk dapat diangkat sebagai pejabat penyidik pembantu. Hal tersebut diungkapkan oleh Penyidik Pembantu berikut ini.

a) Sekurang-kurangnya berpangkat Sersan dua polisi (setara dengan Brigadir dua);

b) Atau pegawai negeri sipil dalam lingkungan Kepolisian negara dengan syarat sekurangkurangnya berpangkat Pengatur Muda (golongan II/a);

c) Diangkat oleh Kepala Kepolisian RI atas $u$ sul komandan atau pimpinan kesatuan masing-masing (Bapak AKBP Suriadin, Wawancara 2 Desember 2015).

Khusus kepangkatan pegawai negeri sipil di lingkungan kepolisian menjadi pejabat penyidik pembantu, yang bersangkutan harus mempunyai keahlian atau kekhususan dalam bidang tertentu. Tanpa syarat tersebut, tidak ada alasan atau urgensi untuk mengangkat mereka menjadi pejabat penyidik pembantu. Syarat kepangkatan penyidik pembantu, lebih rendah dari pangkat jabatan penyidik. Berdasarkan hierarki dan organisatoris, penyidik pembantu diperbantukan kepada penyidik, oleh karena itu kepangkatan mereka harus lebih rendah dari penyidik.

Penyidik pembantu tidak mesti terdiri dari anggota dari anggota Polri, tetapi bisa diangkat dari kalangan pegawai sipil Polri, sesuai dengan keahlian khusus yang mereka miliki dalam bidang tertentu. Misalnya, ahli kimia atau ahli patologi. Apabila pegawai sipil Polri yang demikian tidak bisa diangkat menjadi penyidik pembantu, mungkin akan menimbulkan hambatan dalam pelaksanaan penyidikan. Sebab di kalangan anggota Polri sendiri, yang memiliki syarat kepangkatan dan keahlian tertentu mungkin masih sangat langka. Itu sebab utama yang menjadi motivasi keperluan penyidik pembantu dapat diangkat dari kalangan pegawai negeri. Hal tersebut diungkapkan oleh Penyidik Pembantu berikut ini.

"Penyidik pegawai negeri sipil diberi wewenang khusus oleh undang-undang. Penyidik pegawai negeri sipil diatur dalam pasal 6 ayat 1 huruf $b$ [13], yaitu pegawai negeri sipil yang mempunyai fungsi dan wewenang sebagai penyidik. Pada dasarnya wewenang yang mereka miliki bersumber pada ketentuan undang-undang pidana khusus, ang telah menetapkan sendiri pemberian wewenang penyidikan pada salah satu pasal" (Bapak AKBP Suriadin, Wawancara 2 Desember 2015).
Pejabat penyidik Polri, memberi wewenang kepada pejabat pegawai negeri sipil yang bersangkutan untuk melakukan penyidikan. Misalnya, Undang-undang Nomor 15 Tahun 2001 tentang Merek, Undang-undang Nomor 16 Tahun 2000 tentang Ketentuan Umum dan Tata Cara Perpajakan, dalam undang-undang tersebut telah ditunjuk pegawai negeri sipil sebagai penyidik dalam peristiwa tindak pidana ekonomi. Akan tetapi harus diingat bahwa penyidik pegawai negeri sipil hanya terbatas sepanjang yang menyangkut dengan tidan pidana yang diatur dalam undang-undang pidana khusus itu. Ini sesuai dengan pembatasan wewenang yang disebutkan dalam pasal 7 ayat 2 [13] yang menentukan bahwa penyidik pegawai negeri sipil sebagaimana yang dimaksud pada pasal 6 ayat 1 huruf $b$ mempunyai wewenang sesuai dengan undang-undang yang menjadi landasan hukumnya masing-masing dan dalam pelaksanaan tugasnya berada di bawah koordinasi dan pengawasan penyidik Polri.

Pelaksanaan penyidikan selalu harus diawali dengan suatu laporan atau pengaduan, sebagaimana yang dimaksudkan dalam Pasal 1 butir 24 [13]. Adapun laporan itu sendiri adalah pemberitahuan yang disampaikan oleh seseorang karena hak atau kewajiban berdasarkan undang-undang kepada pejabat yang berwenang tentang telah atau sedang atau diduga akan terjadi tindak pidana. Seperti terlihat dari hasil wawancara dengan selaku Pelaksana Tugas Kewilayahan berikut ini.

"Pengaduan adalah pemberitahuan yang disertai permintaan oleh pihak yang berkepentingan kepada pejabat yang berwenang untuk menindak menurut hukum seseorang yang telah melakukan tindak pidana aduan yang merugikannya. Sebagaimana hal ini telah ditegaskan dalam pasal 1 butir 25" [13] (Bapak AKBP Arief Yuswanto, Wawancara 3 Desember 2015).

Perbedaan hakiki antara pelaporan dan pengaduan tidak ada peninjauan dari segi formal. Keduanya samasama mengandung arti pemberita-huan seseorang kepada pejabat yang berwenang menerima laporan dan pengaduan. Perbedaannya terletak pada jenis hukum materiil atau jenis kejahatan tindak pidana yang diberitahukan. Pada laporan, pemberitahuan bersifat umum, meliputi seluruh jenis tindak pidana. Sedang pada pengaduan, merupakan pemberitahuan dari seseorang kepada pejabat yang berwenang tentang tindak pidana aduan atau klacht delik yang menimbulkan kerugian kepadanya, seperti tindak pidana yang diatur dalam pasal 367 ayat 2 [13].

Adapun pengajuan laporan atau pengaduan diatur dalam Bab XIV KUHAP tentang penyidikan yaitu dalam pasal 108 [13] yaitu seperti terlihat dari hasil wawancara dengan selaku Pelaksana Tugas Kewilayahan berikut ini.

a) Setiap orang yang mengalami, melihat, menyaksikan atau menjadi korban peristiwa pidana, berhak untuk mengajukan laporan atau pengaduan kepada penyelidik atau penyidik; 
b) Setiap orang yang mengetahui permufakatan jahat untuk melakukan tindak pidana terhadap ketenteraman dan keamanan umum atau terhadap jiwa atau terhadap hak milik, wajib seketika itu juga melaporkan hal tersebut kepada penyelidik atau penyidik;

c) Pegawai negeri dalam rangka menjalankan tugas yang mengetahui terjadi peristiwa yang merupakan tindak pidana wajib segera melaporkan hal itu kepada penyelidik atau penyidik (Bapak AKBP Arief Yuswanto, Wawancara 3 Desember 2015).

Pada dasarnya undang-undang dalam hal ini KUHAP telah membagi kelompok pelapor, yaitu:

[1] Orang yang diberi hak melapor atau mengadu, yakni orang yang mengalami, melihat, menyaksikan atau orang yang menjadi korban tindak pidana yang terjadi, berhak menyampaikan laporan kepada penyelidik atau penyidik. Pada ketentuan ini, hak menyampaikan laporan atau pengaduan, tidak diberi kepada orang yang mendengar. Pendengaran tidak dimasukkan dalam kategori orang yang berhak untuk melapor adalah realistis dan rasional;

[2] Kelompok pelapor atas dasar kewajiban hukum, ini adalah kebalikan yang pertama. Jika pada yang pertama sifat pelaporan merupakan hak, boleh dipergunakan, tidak dapat dipaksa harus melapor atau mengadu. Akan tetapi kelompok pelapor yang kedua, sifat pelaporan merupakan kewajiban bagi orang-orang tertentu, yaitu orang yang mengetahui permufakatan untuk melakukan tindak pidana terhadap ketenteraman umum, atau terhadap jiwa atau hak milik. Atau setiap pegawai negeri dalam rangka melakukan tugas, mengetahui tentang terjadinya peristiwa tindak pidana. Sesuai dengan ketentuan pasal 5 dan pasal 7 [13] dihubungkan pula dengan pasal 108 [13], pelaporan atau pengaduan disampaikan atau diajukan kepada: penyidik, atau;

Atas dasar adanya pengaduan atau laporan tersebut, untuk kepentingan pemeriksaan penyidik dan penyidik pembantu mempunyai wewenang melakukan pemanggilan terhadap, seperti diungkapkan oleh selaku Pengawas Dan Pembantu Pimpinan berikut.

Pertama, Tersangka, yang karena perbuatannya

atau keadaannya berdasarkan bukti permulaan

patut diduga sebagai pelaku tindak pidana;

Kedua, Saksi, yang dianggap perlu untuk

diperiksa (Bapak AKBP Samsul Hadi, Wawancara

3 Desember 2015)

Pemanggilan saksi harus dilakukan penyidik dengan berhati-hati dan teliti. Jangan sampai saksi yang dipanggil, ternyata tidak dapat memberikan keterangan apapun. Sangat diharapkan agar kata-kata yang dianggap perlu dalam ketentuan ini, jangan dipergunakan sedemikian rupa untuk memanggil setiap orang tanpa didahului penelitian dan pertimbangan yang matang sesuai dengan urgensi pemeriksaan, dihubungkan dengan keluasan pengetahuan yang dimiliki saksi mengenai peristiwa pidana yang bersangkutan. Pengalaman cukup memberi kenyataan, berapa banyak orang yang dipanggil untuk diperiksa sebagai saksi, padahal orang itu sudah menjelaskan sama sekali tidak mengetahui peristiwa pidana yang sedang diperiksa.

Kadang-kadang seorang saksi berulang-ulang diperiksa, hanya untuk pertanyaan yang itu juga, sehingga sering didengar kejengkelan seseorang jika dipanggil sebagai saksi, karena dengan pemanggilan untuk diperiksa sebagai saksi yang bersangkutan dapat membayangkan akan terjadi pengalaman cara pemeriksaan yang tak berujung pangkal, di samping cara pelayanan yang tidak manusiawi. Sebenarnya untuk memanggil dan menjadikan seseorang untuk diperiksa sebagai saksi, pejabat penyidik atau penyidik pembantu harus benar-benar berpedoman kepada kriteria yang ditentukan oleh Pasal 1 butir 26 KUHAP, yaitu seperti diungkapkan oleh selaku Pengawas Dan Pembantu Pimpinan berikut.

[1] Saksi harus orang yang mendengar sendiri;

[2] Saksi harus melihat sendiri;

[3] Saksi harus mengalami sendiri peristiwa pidananya, dan;

[4] Orang yang bersangkutan dapat menjelaskan sumber pengetahuan akan apa yang ia dengar, ia lihat, dan ia alami sendiri (Bapak AKBP Samsul Hadi, Wawancara 4 Desember 2015)

Berpedoman kepada ketentuan yang disebut di atas, maka dapat dihindari pemeriksaan atau pemanggilan saksi yang tidak memenuhi syarat-syarat tersebut diatas. Khusus pemanggilan tersangka, harus diperhatikan ketentuan pasal 1 butir 14 [13], sehingga seseorang baru dapat diduga sebagai tersangka berdasarkan adanya bukti permulaan. Penyidik harus lebih dulu memperoleh atau mengumpulkan bukti permulaan, baru dapat menjatuhkan dugaan terhadap seseorang. Artinya cukup fakta dan keadaan berdasar informasi yang sangat dipercaya, bahwa tersangka sebagai pelaku tindak pidana berdasar bukti dan tidak boleh semata-mata berdasar konklusi. Jangan seperti praktek penegakan hukum di masa lalu, penyidik sudah langsung menduga, menangkap, dan menahan seseorang walaupun bukti permulaan belum ada. Tanpa berusaha mengumpulkan bukti permulaan, seseorang telah diperiksa dan ditahan. Akibatnya, terjadi cara-cara kekerasan dan pemerasan pengakuan sampai-sampai sering mengalami cacat seumur hidup.

Agar pemanggilan yang dilakukan aparat penegak hukum pada semua tingkat pemeriksaan dapat dianggap sah dan sempurna, maka harus dipenuhi syarat-syarat yang telah ditentukan undang-undang. Ketentuan syarat sahnya panggilan pada tingkat pemeriksaan penyidikan diatur dalam pasal 112, pasal 119 dan pasal 227 [13]. Menurut ketentuan [14] tersebut surat panggilan harus memuat, seperti diungkapkan oleh selaku Pengawas Dan Pembantu Pimpinan berikut.

[1] Alasan pemanggilan harus disebut, sehingga orang yang dipanggil tahu untuk 
kepentingan apa ia dipanggil, apakah sebagai tersangka, saksi, atau sebagai ahli. Sering dijumpai surat panggilan yang kabut tidak dicantumkan secara tegas apakah dipanggil sebagai saksi atau tersangka. Misalnya hanya menyebut dipanggil menghadap tanggal sekian sehubungan dengan pemeriksaan perkara pidana yang dituduhkan berdasar pasal 338 KUHP. Bentuk pemanggilan seperti ini tidak memberikan kepastian hukum, seolah-olah sengaja untuk menakuti orang yang dipanggil, sementara ia hanya diperiksa sebagai saksi. Pemanggilan seperti ini disamping bentuknya kabur, sekaligus juga melanggar landasan penegakan kepastian hukum bagi orang yang dipanggil. Oleh karena itu, dengan berlakunya KUHAP yang dalam salah satu tujuannya adalah menegakkan kepastian hukum, harus tegas dijelaskan status orang yang dipanggil apakah sebagai tersangka atau saksi;

[2] Surat panggilan harus ditanda-tangani oleh pejabat penyidik, dan sedapat mungkin di samping tanda tangan harus dibubuhi tanda cap jabatan penyidik. Adapun cap jabatan stempel bukan mutlak, karena yang mutlak adalah tanda tangan pejabat, sesuai dengan penjelasan pasal 112 ayat 1 KUHAP yang menegaskan bahwa surat panggilan yang ditanda-tangani oleh pejabat penyidik yang berwenang (Bapak AKBP Samsul Hadi, Wawancara 4 Desember 2015).

Antara tanggal hari diterimanya surat panggilan, dengan hari tanggal orang yang dipanggil diharuskan memenuhi panggilan harus ada tenggang waktu yang layak (pasal 112 ayat 1 [13] ). Tenggang waktu mana adalah selambat-lambatnya tiga hari sebelum hadir yang ditentukan dalam surat panggilan.

Dengan demikian, ada dua alternatif, pertama tenggang waktu panggilan dengan keharusan kehadiran menghadap pejabat yang memanggil, harus memperlihatkan tenggang waktu yang wajar. Sedang pada alternatif kedua, undang-undang menetapkan sendiri tenggang waktu minimum yakni paling lambat tiga hari dari tanggal yang ditentukan untuk memenuhi panggilan, panggilan tersebut sudah disampaikan kepada yang dipanggil. Hal ini sesuai dengan apa yang diatur dalam penjelasan pasal 152 ayat 2 dan pasal 227 ayat 1 [13], yang dimaksud selambat-lambatnya tiga hari, bukan dari tanggal dikeluarkan surat panggilan, tetapi tiga hari dari tanggal disampaikan kepada yang bersangkutan. Hal tersebut diungkapkan oleh selaku Ketua Sektret Penyidik berikut ini.

"Apabila panggilan tidak memenuhi ketentuan, panggilan itu tidak memenuhi syarat untuk dianggap sah. Oleh karena itu, orang yang dipanggil dapat memilih boleh datang memenuhi panggilan atau sebaliknya menolak untuk memenuhi. Bilamana yang kedua yang dipilih oleh orang yang dipanggil, mewajibkan pejabat yang bersangkutan untuk melakukan panggilan resmi sekali lagi” (Bapak AKBP Stario $\mathrm{H}$, Wawancara 4 Desember 2015).

Bilamana persyaratan surat panggilan telah dipenuhi, baik tersangka, terdakwa, saksi, atau ahli wajib datang memenuhi panggilan. Tidak ada satu ketentuan hukum yang memperbolehkan pemenuhan panggilan dengan jalan memperwakilkan kepada orang lain, kecuali dalam pemeriksaan pelanggaran lalu lintas, terdakwa dapat menunjuk seorang dengan surat kuasa untuk mewakilinya di persidangan (pasal 213 [13]).

Apabila yang dipanggil tidak mentaati panggilan tersebut, orang yang bersangkutan telah melanggar kewajiban yang dibebankan hukum kepadanya berdasarkan pasal 112 ayat 2 [13]. Namun, ketentuan pasal 112 ayat 2 [13] sudah mengatur sendiri cara selanjutnya terhadap keingkaran kewajiban tersebut dengan jalan, hal tersebut diungkapkan oleh selaku Ketua Sektret Penyidik berikut ini.

[1] Jika panggilan yang pertama tidak dipenuhi yang bersangkutan, sekalipun panggilan itu sudah dilakukan sesuai dengan cara-cara yang ditentukan, maka panggilan dilakukan untuk kedua kalinya;

[2] Apabila panggilan kedua tidakjuga dipenuhi oleh orang yang bersangkutan, pejabat penyidik mengeluarkan perintah kepada petugas untuk membawanya ke hadapan pejabat yang memanggilnya (Bapak AKBP Stario H, Wawancara 5 Desember 2015).

Proses selanjutnya adalah pemeriksaan di muka pejabat penyidik dengan jalan menghadirkan tersangka, saksi, atau ahli. Pemeriksaan berarti, petugas penyidik berhadapan langsung dengan tersangka, para saksi atau ahli. Sebagaimana telah dijelaskan di atas bahwa penyidikan merupakan rangkaian tindakan penyidik dalam hal dan dengan cara yang diatur dalam undangundang untuk mencari serta mengumpulkan bukti. Dengan bukti yang ditemukan dan dikumpulkan, tindak pidana yang terjadi akan menjadi terang dan jelas dapat menemukan tersangka yang menjadi pelaku tindak pidana yang sedang disidik.

Dari ketentuan pasal 1 butir 2 [13] dapat dimengerti bahwa tindakan penyidikan tiada lain adalah rangkaian tindakan mencari dan mengumpulkan bukti, agar peristiwa tindak pidananya menjadi terang serta tersangkanya dan berkas perkara tindak pidananya dapat diajukan kepada penuntut umum dan untuk selanjutnya tersangka dihadapkan jaksa kepada hakim di muka persidangan pengadilan. Artinya begitu pemeriksaan tersangka dan saksi-saksi atau ahli di hadapan petugas penyidik, dapat dikatakan merupakan rangkaian terakhir tindakan penyidik sebelum menyampaikan hasil penyidikan kepada penuntut umum, hal tersebut diungkapkan oleh selaku Ketua Sektret Penyidik berikut ini.

"Pemeriksaan di muka petugas penyidik baru dapat dilaksanakan penyidik setelah dapat mengumpulkan bukti permulaan serta telah menemukan orang yang diduga sebagai tersangka. Penyidik yang mengetahui sendiri 
terjadinya peristiwa pidana atau oleh karena berdasar laporan ataupun berdasar pengaduan, dan menduga peristiwa itu merupakan tindak pidana, penyidik wajib segera melakukan tindakan penyidikan yang diperlukan, dan rangkaian akhir tindakan yang diperlukan itu adalah pemeriksaan langsung tersangka dan saksi-saksi maupun ahli" (Bapak AKBP Stario H, Wawancara 5 Desember 2015).

Pada saat penyidik mulai melakukan penyidikan terhadap peristiwa yang diduga merupakan tindak pidana, penyidik memberitahukan hal itu kepada penuntut umum. Pemberitahuan semacam ini ditentukan dalam pasal 109 ayat 1 [13] bahwa dalam hal penyidik telah mulai melakukan penyidikan suatu peristiwa yang merupakan tindak pidana, penyidik memberitahukan hal itu kepada penuntut umum. Alasan mengkategorikan pemberitahukan tersebut sebagai kewajiban, pasal 109 ayat 1 [13] tidak memuat perkataan wajib, dan dalam penjelasan pasal 109 [13], juga tidak dijumpai perkataan wajib.

Titik pangkal pemeriksaan di hadapan penyidik ialah tersangka, dari dialah diperoleh keterangan tentang peristiwa pidana yang sedang diperiksa. Akan tetapi, sekalipun tersangka yang menjadi titik tolak pemeriksaan, terhadapnya harus diberlakukan asas accusatoir. Tersangka harus ditempatkan pada kedudukan manusia yang memiliki harkat martabat, ia harus dinilai sebagai subyek bukan sebagai obyek. Perbuatan tindak pidana yang dilakukan itulah yang menjadi obyek pemeriksaan, ke arah kesalahan tindak pidana yang dilakukan pemeriksaan ditujukan. Tersangka harus dianggap tak bersalah, sesuai dengan prinsip hukum praduga tak bersalah atau presumption of innocence sampai diperoleh putusan pengadilan yang telah berkekuatan tetap. Hal tersebut diungkapkan oleh Pengawas Dan Pembantu Pimpinan Penyidik berikut ini.

"Pada pemeriksaan tindak pidana, tidak selamanya hanya tersangka saja yang harus diperiksa, adakalanya diperlukan pemeriksaan saksi atau ahli, demi untuk terang dan jelasnya peristiwa pidana yang disangkakan. Sedangkan kepada tersangka harus ditegakkan perlindungan harkat martabat dan hak-hak asasi, kepada saksi dan ahli, harus juga diberlakukan dengan cara yang berperikemanusiaan dan beradab" (Bapak AKBP Sudirman, Wawancara 7 Desember 2015).

Sehubungan dengan pemeriksaan tersangka, undang-undang telah memberi beberapa hak perlindungan terhadap hak asasinya serta perlindungan terhadap haknya untuk mempertahankan kebenaran dan pembelian diri seperti yang diatur pada Bab VI, pasal 50 sampai dengan pasal 68 [13].

Hak tersangka untuk segera mendapat pemeriksaan oleh, namun undang-undang tidak menjelaskan lebih lanjut tentang kata segera. Akan tetapi, dari pengertian bahasa Indonesia yang dimaksud dengan secepat mungkin adalah sesegera mungkin dengan tanpa menunggu lebih lama. Dengan tujuan untuk menjauhkan kemungkinan terkatung-katungnya nasib orang yang disangka, jangan sampai lama tidak mendapat pemeriksaan, sehingga dirasakan tidak ada kepastian hukum, terjadinya perlakuan sewenangwwenang dan ketidak wajaran.

Semua yang diterangkan tersangka tentang apa yang sebenarnya telah dilakukannya sehubungan dengan tindak pidana yang disangkakan kepadanya, dicatat oleh penyidik dengan seteliti-telitinya.. pencatatan disesuaikan dengan kata-kata dan kalimat yang dipergunakan tersangka. Namun, kita berpendapat prinsip ini jangan terlampau kaku ditafsirkan. Penyidik boleh menyesuaikan dengan susunan kalimat yang lebih memenuhi kemudahan membacanya, asal isi dan maksud yang dikemukakan tersangka tidak diubah dan diperkosa. Hal tersebut diungkapkan oleh Pengawas Dan Pembantu Pimpinan Penyidik berikut ini.

"Sesuai dengan ketentuan, penyidik menyampaikan pemberitahuan kepada penuntut umum apabila penyidik telah mulai melakukan tindakan penyidikan. Pemberitahuan itu merupakan pelaksanaan yang harus dilakukan penyidik bersamaan dengan tindakan yang dilakukannya. Sebagaimana yang ditegaskan, pemberitahuan penyidikan kepada penuntut umum, dianggap kewajiban yang harus dilakukan dengan cara tertulis maupun secara lisan yang disusul kemudian dengan tulisan. Urgensi pemberitahuan tersebut berkaitan dengan hak penuntut umum mengajukan permintaan kepada praperadilan untuk memeriksa sah atau tidaknya penghentian penyidikan" (Bapak AKBP Sudirman, Wawancara 7 Desember 2015).

Undang-undang memberi wewenang peng-hentian penyidikan kepada penyidik, yakni penyidik berwenang bertindak menghentikan penyidikan yang telah dimulainya. Hal ini ditegaskan pasal 109 ayat 2 yang memberi wewenang kepada penyidik untuk menghentikan penyidikan yang sedang berjalan.

Undang-undang telah menyebutkan secara limitative alasan yang dapat dipergunakan penyidik sebagai dasar penghentian penyidikan. Penyebutan atau penggarisan alasan-alasan tersebut penting, guna menghindari kecenderungan negatif pada diri pejabat penyidik. Dengan penegasan ini, undang-undang mengharapkan supaya di dalam mem-pergunakan wewenang penghentian penyidikan, penyidik mengujinya kepada alasan-alasan yang telah ditentukan. Tidak semuanya tanpa alasan yang dapat dipertanggungjawabkan menurut hukum, serta sekaligus pula akan memberi landasan perujukan bagi pihakpihak yang merasa keberatan atas sah tidaknya penghentian penyidikan menurut hukum. Demikian juga bagi praperadilan, penegasan alasan-alasan penghentian tersebut merupakan landasan dalam pemeriksaan sidang praperadilan, jika ada permintaan pemeriksaan atas tidaknya penghentian penyidikan.

Penyidikan dapat dilakukan hanya atas dasar, bilamana dalam penyidikan tersebut terjadi hal-hal sebagai berikut: 
1. Tidak diperoleh bukti yang cukup

Apabila penyidik tidak memperoleh cukup bukti untuk menuntut tersangka atau bukti yang diperoleh penyidik tidak memadai untuk membuktikan kesalahan tersangka jika diajukan ke depan sidang pengadilan, maka hakim berhak melakukan penghentian penyidikan terhadap tindak pidana. Seperti diungkapkan oleh selaku Pengawas Dan Pembantu Pimpinan berikut.

"Ditinjau dari segi pemberian wewenang ini membina sikap mental penyidik untuk tidak secara serampangan mengajukan begitu saja segala hasil penyidikan yang telah dilakukannya. Diharapkan lebih selektif mengajukan setiap kasus yang mereka periksa, apakah cukup bukti atau tidak sebelum perkara dilimpahkan ke tangan penuntut umum. Jangan lagi seperti yang dialami selama ini, ada atau tidak ada bukti penyidik tidak peduli. Pokoknya sekali tindak pidana mereka periksa langsung begitu saja diajukan ke penuntut umum untuk diteruskan ke pengadilan sekalipun tidak ada bukti yang dapat dipegang membuktikan kesalahan tersangka" (Bapak AKBP Samsul Hadi, Wawancara 7 Desember 2015)

Pertimbangan hukum penghentian penyidikan terhadap tindak pidana di Polres Kota Bima yaitu tidak diperoleh bukti yang cukup, oleh karena itu pada prinsipnya penghentian penyidikan, dengan syarat tidak memiliki bukti yang kuat dan disertai dengan alasan yang mendasar dan logis. Alasan yang mendasar dan logis tersebut mengandung arti bahwa alasan yang menjadi dasar pertimbangan hukum penghentian penyidikan harus dapat dibuktikan kebenarannya dan diperkuat atau didukung oleh bukti-bukti lain yang menunjukkan bahwa alasan pertimbangan hukum penghentian penyidikan tersebut benar dan dapat dibuktikan.

2. Peristiwa yang disangkakan bukan tindak pidana

Apabila dari hasil penyidikan dan pemeriksaan, penyidik berpendapat apa yang disangkakan terhadap tersangka bukan merupakan perbuatan pelanggaran dan kejahatan, dalam hal ini berwenang menghentikan penyidikan. Hal tersebut diungkapkan oleh Penyidik satu berikut ini.

"Jika apa yang disangkakan bukan kejahatan maupun pelanggaran pidana yang termasuk kompetensi peradilan umum, jadi tidak merupakan pelanggaran dan kejahatan seperti yang diatur dalam KUHP atau dalam peraturan perundang-undangan tindak pidana khusus yang termasuk dalam ruang lingkup wewenang peradilan umum, penyidikan beralasan dihentikan. Bahkan merupakan keharusan bagi penyidik untuk menghentikan pemeriksaan penyidikan" (Bapak AKBP Munawar, Wawancara 8 Desember 2015).

Pertimbangan hukum penghentian penyidikan terhadap tindak pidana di Polres Kota Bima yaitu peristiwa yang disangkakan bukan tindak pidana, kendati diakui, kadang-kadang sangat sulit menarik garis yang tegas tentang apakah suatu tindakan yang dilakukan seorang, termasuk dalam ruang lingkup tindak pidana pelanggaran dan kejahatan. Kesulitan ini sering dijumpai dalam peristiwa-peristiwa yang dekat hubungannya dengan ruang lingkup hukum perdata.

3. Penghentian penyidikan demi hukum

Penghentian penyidikan atas dasar alasan demi hukum pada pokoknya sesuai dengan alasan-alasan hapusnya hak menuntut dan hilangnya hak menjalankan pidana antara lain: tersangka meninggal dunia dan karena daluarsa. Seperti terlihat dari hasil wawancara dengan selaku Pelaksana Tugas Kewilayahan berikut ini.

"Bilamana ternyata suatu perkara pidana dihentikan penyidikannya, dengan tanpa terdapat alasan yang dibenarkan oleh undangundang dalam hal ini KUHAP. Artinya perkara pidana tersebut ada cukup bukti, perkara pidana itu merupakan tindak pidana murni dan tidak terdapat alasan untuk menutup perkara dimaksud atas dasar ditutup demi hukum, maka upaya yang dapat dilakukan guna menegakkan Hukum Pidana bagi para pelanggarnya adalah dengan mengajukan praperadilan" (Bapak AKBP Arief Yuswanto, Wawancara 8 Desember 2015).

Pertimbangan hukum penghentian penyidikan terhadap tindak pidana di Polres Kota Bima yaitu adanya penghentian penyidikan demi hukum, seperti dengan adanya praperadilan merupakan hal baru dalam dunia peradilan Indonesia. Praperadilan merupakan salah satu lembaga baru yang diperkenalkan KUHAP di tengah-tengah kehidupan penegakan hukum. Praperadilan dalam KUHAP, ditempatkan dalam Bab X Bagian Kesatu sebagai salah satu bagian ruang lingkup wewenang mengadili bagi Pengadilan Negeri.

Di tinjau dari segi struktur dan susunan peradilan, Praperadilan bukan lembaga pengadilan yang berdiri sendiri. Bukan pula sebagai instansi tingkat peradilan yang mempunyai wewenang memberi putusan akhir atas suatu kasus peristiwa pidana. Praperadilan hanya suatu lembaga baru yang ciri dan eksistensinya berada dan merupakan kesatuan yang melekat pada Pengadilan Negeri, dan sebagai lembaga pengadilan, hanya dijumpai pada tingkat Pengadilan Negeri sebagai satuan tugas yang tidak terpisah dari Pengadilan Negeri. Seperti terlihat dari hasil wawancara dengan selaku Pelaksana Tugas Kewilayahan berikut ini.

"Dari gambaran di atas, eksistensi dan kehadiran Praperadilan bukan merupakan lembaga peradilan tersendiri. Tetapi hanya merupakan pemberian wewenang dan fungsi baru yang dilimpahkan KUHAP kepada setiap Pengadilan Negeri, sebagai wewenang dan fungsi tambahan Pengadilan Negeri yang telah ada selama ini. Seperti yang sudah diketahui, demi untuk terlaksananya kepentingan pemeriksaan tindak pidana, undang-undang memberi kewenangan kepada penyidik dan penuntut untuk melakukan tindakan upaya paksa berupa penangkapan, penahanan, penyitaan dan sebagainya. Demikian pula penyidik diberikan kewenangan untuk melakukan penghentian penyidikan atas dasar alasan-alasan yang dibenarkan oleh KUHAP" 
(Bapak AKBP Suanardi, Wawancara 8 Desember 2015).

Praperadilan yang dilakukan terhadap penghentian penyidikan secara tidak sah mempunyai misi dan motivasi tertentu. Praperadilan mempunyai maksud dan tujuan yang hendak ditegakkan dan dilindungi, yakni tegaknya hukum dan perlindungan hak asasi korban dalam semua tingkat pemeriksaan perkara pidana.

Selain pertimbangan hukum di atas, alasan lain penghentian penyidikan terhadap tindak pidana yang sering dilakukan oleh masyarakat Bima yaitu melakukan perdamaian di luar persidangan. Adapun hal yang melatar belakangi adalah karena adanya kesepakatan antara kedua belah pihak yaitu terdakwa dan korban, dan biasanya hal ini terjadi karena terdakwa mau menanggung semua kewajiban korban, misalnya pengobatan, ganti rugi dan sebagainya.

Berdasarkan hasil penelitian, maka dapat disimpulkan bahwa pertimbangan hukum penghentian penyidikan terhadap tindak pidana di Polres Kota Bima meliputi tidak diperoleh bukti yang cukup, peristiwa yang disangkakan bukan tindak pidana dan penghentian penyidikan demi hukum.

\section{Akibat Hukumnya Jika Terjadi Penghentian Penyidikan Terhadap Tindak Pidana di Polres Kota Bima \\ Penghentian penyidikan merupakan tindakan} penyidik dalam upaya tidak melanjutkan perkara pidana yang telah dilaporkan oleh pihak korban. Penghentian penyidikan adalah merupakan wewenang pihak penyidik atas dasar alasan hukum yang membenarkannya, yaitu tidak diperoleh bukti yang cukup, peristiwa yang disangkakan bukan merupakan tindak pidana, dan penghentian penyidikan demi hukum. Akibat hukumnya jika terjadi penghentian penyidikan terhadap tindak pidana di Polres Kota Bima yaitu sebagai berikut

1. Mempercepat proses hukum

Terlepas dari diterima atau tidaknya penghentian penyidikan terhadap tindak pidana oleh penyidik, dengan adanya penghentian penyidikan tersebut pasti akan mempengaruhi proses penghentian penyidikan di Polres Kota Bima. Oleh karena itu perlu kesiapan dari penyidik, terutama dalam hal penguasaan seluk-beluk proses penghentian penyidikan. Selengkapnya dapat dilihat dari hasil wawancara dengan Penyidik Pembantu berikut.

"Hal ini penting mengingat pengaruh proses penghentian penyidikan tersebut sangat luas mulai dari penilaian pembuktian sampai pada putusan. Implikasi dari adanya proses penghentian penyidikan terhadap kekuatan alat bukti, dapat diketahui setelah adanya penilaian hakim terhadap alasan proses penghentian penyidikan tersebut, apakah penyidik menerima atau menolak alasan proses penghentian penyidikan tersebut. Proses penghentian penyidikan mengakibatkan terdakwa bebas murni vrijspraak atas apa yang didakwakan (tuntutan) kepadanya dalam surat dakwaan, upaya hukum yang dapat dilakukan oleh Penuntut Umum antara lain, kasasi dan terdakwa dapat mengajukan rehabilitasi” (Bapak Efendi, Wawancara 8 Desember 2015)

Akibat hukumnya jika terjadi penghentian penyidikan terhadap tindak pidana di Polres Kota Bima yaitu dapat mempercepat proses hukum karena apabila penyidik menerima alasan penghentian penyidikan, berarti keterangan yang terdapat dalam berita acara penyidikan dianggap "tidak benar" dan keterangan itu tidak dapat dipergunakan sebagai landasan untuk membantu menemukan bukti di sidang pengadilan. Sebaliknya, apabila alasan penghentian penyidikan tidak dapat dibenarkan maka keterangan pengakuan yang tercantum dalam berita acara penyidikan tetap dianggap benar dan dapat dipergunakan sebagai landasan untuk membantu menemukan bukti di sidang pengadilan.

\section{Sebagai Kekuatan Alat Bukti}

Mengenai proses ganti rugi yang merupakan bagian dari Praperadilan (Pasal 77 [13]) tidak mutlak tergantung kepada terdakwa. Tidak terkait dengan proses pembuktian, hal yang terjadi ialah proses penyidikan cacat hukum yang mengakibatkan dakwaan batal demi hukum, alternatifnya ialah dilakukan pemeriksaan kembali dalam proses penyidikan (BAP) agar hak azasi tersangka atau terdakwa terjamin/terlindungi. Selengkapnya dapat dilihat dari hasil wawancara dengan Penyidik Pembantu berikut.

"Bila proses penghentian penyidikan tidak mendasar, karena dinilai alasan penghentian penyidikan tidak berdasar dan tidak logis, maka penolakan tersebut ikut membawa dampak bagi kekuatan alat bukti keterangan terdakwa itu sendiri, yaitu dengan ditolaknya penghentian penyidikan kembali tersebut, Penyidik menilai bahwa penghentian penyidikan di depan penyidiklah yang mengandung unsur kebenaran dan mempunyai nilai pembuktian, sedangkan keterangan terdakwa di persidangan yang menyangkal semua isi BAP dinilai tidak benar dan tidak ada nilainya sama sekali dalam pembuktian" (Bapak Efendi, Wawancara 9 Desember 2015).

Penyididik kemudian menganggap penghentian penyidikan di depan penyidik (BAP) dapat digunakan sebagai petunjuk untuk membuktikan kesalahan terdakwa. Karena pada dasarnya dengan ditolaknya penghentian penyidikan tersebut berarti pengakuanpengakuan terdakwa yang tertulis dalam BAP diterima sebagai suatu kebenaran yang sangat membantu hakim dalam membuktikan kesalahan terdakwa.

Penggunaan keterangan penghentian penyidikan sebagai petunjuk ini dipertegas dengan adanya Putusan. Selengkapnya dapat dilihat dari hasil wawancara dengan Penyidik Pembantu berikut.

"Bahwa pengakuan-pengakuan di muka polisi dan jaksa, ditinjau dalam hubungannya satu 
sama lain, dapat dipergunakan sebagai petunjuk untuk menetapkan kesalahan terdakwa" (Bapak

Rahmat, Wawancara 9 Desember 2015).

Isi putusan mengandung kaidah bahwa keterangan pengakuan yang diberikan di luar sidang, dapat dipergunakan hakim sebagai "petunjuk" untuk menetapkan kesalahan terdakwa. Dari penjelasan di atas dapat dilihat bahwa penghentian penyidikan yang ada dalam BAP, maka terhadap keterangan yang tertulis dalam BAP tersebut, oleh penyidik kemudian dijadikan petunjuk dalam menetapkan kesalahan terdakwa.

3. Mempermudah penyidik dalam menyelesaiankan kasus

Adapun pertimbangan penyidik menggunakan keterangan dalam BAP sebagai petunjuk, adalah karena keterangan tersebut secara utuh menggambarkan kejadian peristiwa pidana yang didakwakan. Keutuhan ini mampu melengkapi dan menegaskan alat bukti yang ditemukan dalam proses penyidikan. Dengan kata lain, kedudukan keterangan pengakuan yang diberikan terdakwa di depan pemeriksaan penyidikan, tidak bisa berdiri sendiri. Fungsinya hanya dapat dipergunakan sebagai petunjuk untuk menyempurnakan pembuktian alat bukti lain. Atau berfungsi dan bernilai "untuk mencukupi dan "mengungkapkan" keterbuktian kesalahan terdakwa. Selengkapnya dapat dilihat dari hasil wawancara dengan Penyidik Pembantu berikut.

"Penghentian penyidikan terhadap tindak pidana yang dilakukan dengan dasar bahwa tidak terbukti kebenarannya, karena setelah dilakukan cross check dengan saksi verbalisan dan setelah penyidik melakukan pengamatan atas fakta-fakta dan alat-alat bukti dalam proses penyidikan ternyata tidak satu pun yang dapat membenaran alasan penghentian penyidikan terhadap tindak pidana tersebut. Bahkan dengan ditolaknya penghentian penyidikan terhadap tindak pidana tersebut, penyidik kemudian menjadikan keterangan dalam BAP sebagai petunjuk dalam membuktikan kesalahan terdakwa. Penyangkalan terdakwa yang melalui alat bukti lain dapat dibuktikan sebagai kebohongan dapat di terima sebagai alat bukti petunjuk. Sehingga, dengan tidak ada satu pun alat bukti yang mendukung penghentian penyidikan terhadap tindak pidana oleh terdakwa, maka keadaan ini dapat dijadikan petunjuk bagi penyidik dalam menilai atau membuktikan kesalahan terdakwa" (Bapak Hidayat, Wawancara 10 Desember 2015).

Akibat hukumnya jika terjadi penghentian penyidikan terhadap tindak pidana, terhadap kekuatan alat bukti keterangan terdakwa adalah, penyidik akan menilai keterangan terdakwa sebagai suatu keterangan yang tidak mengandung unsur kebenaran dan tidak ada nilainya sama sekali dalam pembuktian (tidak dapat digunakan sebagai alat bukti). Hal tersebut diungkapkan oleh Inspektur Dua Polisi berikut ini.

"Sedangkan bila penghentian penyidikan terhadap tindak pidana atas dasar pencabutan keterangan pengakuan terdakwa diterima, karena alasan penghentian penyidikan yang dapat dibuktikan kebenarannya, hal ini juga akan membawa dampak bagi kekuatan alat bukti keterangan terdakwa itu sendiri, yaitu dengan diterimanya penghentian penyidikan tersebut, penyidik akan menilai bahwa keterangan terdakwa yang mempunyai nilai kebenaran dan dapat digunakan dalam pembuktian, sedangkan terhadap keterangan terdakwa (tersangka) di depan penyidik (BAP) dinyatakan tidak benar dan tidak ada nilainya sama sekali dalam pembuktian" (Bapak Hidayat, Wawancara 10 Desember 2015).

Akibat hukumnya jika terjadi penghentian penyidikan terhadap tindak pidana di Polres Kota Bima, yaitu penyidik akan menilai keterangan terdakwa sebagai suatu keterangan yang mengandung unsur kebenaran dan dapat digunakan sebagai alat bukti.

Berdasarkan hasil penelitian, maka dapat disimpulkan bahwa akibat hukumnya jika terjadi penghentian penyidikan terhadap tindak pidana di Polres Kota Bima meliputi mempermudah penyidik dalam menyelesaiankan kasus, sebagai kekuatan alat bukti dan mempercepat proses hukum.

\section{PEMBAHASAN}

Ruang lingkup penyidikan adalah serangkaian tindakan penyelidik untuk mencari dan menemukan suatu peristiwa yang diduga sebagai tindak pidana guna menentukan dapat atau tidaknya dilakukan penyidikan menurut cara yang diatur dalam undang-undang. Penyidik karena kewajibannya mempunyai wewenang menerima laporan, mencari keterangan dan barang bukti, menyuruh berhenti orang yang dicurigai dan menanyakan serta memeriksa tanda pengenal diri, dan mengadakan tindakan lain menurut hukum yang bertanggung jawab. Berdasarkan ketentuan Pasal 16 ayat 1 [13], untuk kepentingan penyelidikan, penyelidik atas perintah penyidik dapat melakukan penangkapan. Namun untuk menjamin hak-hak asasi tersangka, perintah penangkapan tersebut harus didasarkan pada bukti permulaan yang cukup.

Pertimbangan hukum penghentian penyidikan terhadap tindak pidana di Polres Kota Bima yaitu sebagai berikut:

1) Tidak diperoleh bukti yang cukup

Pertimbangan hukum penghentian penyidikan terhadap tindak pidana di Polres Kota Bima yaitu tidak diperoleh bukti yang cukup, karena pada saat penyedikian bukti yang diperoleh hanya memuat tentang pengakuan, sedangkan bukti otentik tidak ada oleh karena itu pada prinsipnya penghentian penyidikan, dengan syarat tidak memiliki bukti yang kuat dan disertai dengan alasan yang mendasar dan logis. Hal tersebut seperti diungkapkan oleh Bapak AKBP Samsul Hadi, bahwa Pertimbangan hukum penghentian penyidikan terhadap tindak pidana di Polres Kota Bima yaitu tidak diperoleh bukti yang cukup, oleh karena itu pada prinsipnya penghentian penyidikan, dengan syarat tidak memiliki bukti yang kuat dan disertai dengan 
alasan yang mendasar dan logis. Hal tersebut didukung oleh pendapat [15], yang mengemukakan bahwa pertimbangan hukum penghentian penyidikan terhadap tindak pidana jika tidak diperoleh bukti yang cukup.

2) Peristiwa yang disangkakan bukan tindak pidana

Pertimbangan hukum penghentian penyidikan terhadap tindak pidana di Polres Kota Bima yaitu peristiwa yang disangkakan bukan tindak pidana, tetapi merupaka tindak perdata. Hal tersebut seperti diungkapkan oleh Bapak AKBP Munawar, bahwa Pertimbangan hukum penghentian penyidikan terhadap tindak pidana di Polres Kota Bima yaitu peristiwa yang disangkakan bukan tindak pidana, kendati diakui, kadang-kadang sangat sulit menarik garis yang tegas tentang apakah suatu tindakan yang dilakukan seorang, termasuk dalam ruang lingkup tindak pidana pelanggaran dan kejahatan. Hal tersebut didukung oleh pendapat Koesnoe [2], yang mengemukakan bahwa pertimbangan hukum penghentian penyidikan terhadap tindak pidana oyaitu peristiwa yang disangkakan bukan tindak pidana artinya penghentian penyidikan bisa dilakukan jika peristiwa tersebut bukan tindak pidana.

3) Penghentian penyidikan demi hukum

Pertimbangan hukum penghentian penyidikan terhadap tindak pidana di Polres Kota Bima yaitu adanya penghentian penyidikan demi hukum, seperti dengan adanya praperadilan merupakan hal baru dalam dunia peradilan Indonesia. Hal tersebut seperti diungkapkan oleh Bapak AKBP Arief Yuswanto, bahwaPertimbangan hukum penghentian penyidikan terhadap tindak pidana di Polres Kota Bima yaitu adanya penghentian penyidikan demi hukum, seperti dengan adanya praperadilan merupakan hal baru dalam dunia peradilan Indonesia. Hal tersebut didukung oleh pendapat [15], yang mengemukakan bahwa pertimbangan hukum penghentian penyidikan terhadap tindak pidana yaitu dilakukan demi hukum, seperti dapat dilakukan praperadilan.

Senada dengan pendapat [16] bahwa pertimbangan hukum penghentian penyidikan terhadap tindak pidana, apabila dalam penyidikan tersebut, tidak ditemukan bukti yang cukup atau peristiwa tersebut bukanlah peristiwa pidana atau penyidikan dihentikan demi hukum, maka penyidik mengeluarkan Surat Perintah Penghentian Penyidikan ( $\mathrm{SP}_{3}$ ). Apabila surat perintah peng-hentian tersebut telah diterbikan maka penyidikan memberitahukan hal tersebut kepada penuntut umum, tersangka atau keluarganya. Apabila korban atau keluarganya tidak dapat menerima penghentian penyidikan tersebut, maka korban atau keluarganya, sedarah atau berasal dari garis lurus ke atas atau ke bawah sampai dengan derajat ke tiga, dapat mengajukan peradilan kepada ketua pengadilan sesuai dengan daerah hukumnya dan ketentuan peraturan perundangundangan yang berlaku.

Pertimbangan hukum penghentian penyidikan terhadap tindak pidana di Polres Kota Bima meliputi tidak diperoleh bukti yang cukup, peristiwa yang disangkakan bukan tindak pidana dan penghentian penyidikan demi hukum.

Penghentian penyidikan merupakan tindakan penyidik dalam upaya tidak melanjutkan perkara pidana yang telah dilaporkan oleh pihak korban. Penghentian penyidikan adalah merupakan wewenang pihak penyidik atas dasar alasan hukum yang membenarkannya, yaitu tidak diperoleh bukti yang cukup, peristiwa yang disangkakan bukan merupakan tindak pidana, dan penghentian penyidikan demi hukum. Akibat hukumnya jika terjadi penghentian penyidikan terhadap tindak pidana di Polres Kota Bima yaitu sebagai berikut:

4) Mempercepat proses hukum

Penghentian penyidikan tersebut pasti akan mempengaruhi proses penghentian penyidikan di Polres Kota Bima. Oleh karena itu perlu kesiapan dari penyidik, terutama dalam hal penguasaan seluk-beluk proses penghentian penyidikan. Hal tersebut seperti diungkapkan oleh Bapak AKBP Efendi, bahwa akibat hukumnya jika terjadi penghentian penyidikan terhadap tindak pidana di Polres Kota Bima yaitu dapat mempercepat proses hukum karena apabila penyidik menerima alasan penghentian penyidikan, berarti keterangan yang terdapat dalam berita acara penyidikan dianggap "tidak benar" dan keterangan itu tidak dapat dipergunakan sebagai landasan untuk membantu menemukan bukti di sidang pengadilan. Hal tersebut senada dengan pendapat [17], bahwa akibat hukumnya jika terjadi penghentian penyidikan terhadap tindak pidana yaitu dapat mempercepat proses hukum, artinya implikasi dari adanya penghentian penyidikan yaitu penyidikan dianggap "tidak benar" dan keterangan itu tidak dapat dipergunakan sebagai landasan untuk membantu menemukan bukti di sidang pengadilan.

5) Sebagai Kekuatan Alat Bukti

Mengenai proses ganti rugi yang merupakan bagian dari Praperadilan tidak mutlak tergantung kepada terdakwa. Tidak terkait dengan proses pembuktian, hal yang terjadi ialah proses penyidikan cacat hukum yang mengakibatkan dakwaan batal demi hukum, alternatifnya ialah dilakukan pemeriksaan kembali dalam proses penyidikan (BAP) agar hak azasi tersangka atau terdakwa terjamin/terlindungi. Hal tersebut seperti diungkapkan oleh Bapak AKBP Efendi, bahwa penyididik kemudian menganggap penghentian penyidikan di depan penyidik (BAP) dapat digunakan sebagai petunjuk untuk membuktikan kesalahan terdakwa. Hal tersebut senada dengan pendapat [2], bahwa akibat hukumnya jika terjadi penghentian penyidikan terhadap tindak pidana yaitu apabila alasan penghentian penyidikan tidak dapat dibenarkan maka keterangan pengakuan yang tercantum dalam berita acara penyidikan tetap dianggap benar dan dapat dipergunakan sebagai landasan untuk membantu menemukan bukti di sidang pengadilan. 
6) Mempermudah penyidik dalam menyelesaiakan kasus

Adapun pertimbangan penyidik menggunakan keterangan dalam BAP sebagai petunjuk, adalah karena keterangan tersebut secara utuh menggambarkan kejadian peristiwa pidana yang didakwakan. Keutuhan ini mampu melengkapi dan menegaskan alat bukti yang ditemukan dalam proses penyidikan. Hal tersebut seperti diungkapkan oleh Bapak AKBP Hidayat, bahwa akibat hukumnya jika terjadi penghentian penyidikan terhadap tindak pidana, terhadap kekuatan alat bukti keterangan terdakwa adalah, penyidik akan menilai keterangan terdakwa sebagai suatu keterangan yang tidak mengandung unsur kebenaran dan tidak ada nilainya sama sekali dalam pembuktian (tidak dapat digunakan sebagai alat bukti). Hal tersebut senada dengan pendapat [15], bahwa akibat hukumnya jika terjadi penghentian penyidikan terhadap tindak pidana yaitu dapat mempermudah penyidik dalam menyelesaiankan kasus yang berkaitan penghentian penyidikan, artinya penyidik akan menilai keterangan terdakwa sebagai suatu keterangan yang tidak mengandung unsur kebenaran dan tidak ada nilainya sama sekali dalam pembuktian (tidak dapat digunakan sebagai alat bukti).

Akibat hukumnya jika terjadi penghentian penyidikan terhadap tindak pidana di Polres Kota Bima meliputi mempermudah penyidik dalam menyelesaiankan kasus, sebagai kekuatan alat bukti dan mempercepat proses hukum.

\section{E. SIMPULAN DAN SARAN}

Hasil penelitian ini menunjukkan bahwa Pertama, pertimbangan hukum penghentian penyidikan terhadap tindak pidana di Polres Kota Bima meliputi tidak diperoleh bukti yang cukup, peristiwa yang disangkakan bukan tindak pidana dan penghentian penyidikan demi hukum. Kedua, akibat hukumnya jika terjadi penghentian penyidikan terhadap tindak pidana di Polres Kota Bima meliputi mempermudah penyidik dalam menyelesaiankan kasus, sebagai kekuatan alat bukti dan mempercepat proses hukum.

Dengan demikian, disarankan bagi pemerintah, sebagai masukan untuk merumuskan kebijakan terutama mengenai tinjauan yuridis tentang pertimbangan hukum penghentian penyidikan terhadap tindak pidana dan akibat hukumnya dan sebagai sumber informasi dan pengetahuan bagi masyarakat yang belum mengenal tinjauan yuridis sosiologis tentang pertimbangan hukum penghentian penyidikan terhadap tindak pidana dan akibat hukumnya.

\section{UCAPAN TERIMA KASIH}

Penulis mengucapkan terima kasih kepada editor yang senantiasa memberikan saran dan masukan kepada penulis sehingga artikel ilimiah ini selesai dengan baik.

\section{DAFTAR RUJUKAN}

[1] M. R. R. Tresna and H. I. R. Komentar, "Cetakan ke-15, PT,” Pradnya Paramita, Jakarta, 1996.

[2] M. Koesnoe, A. Boediarto, S. S. Soewandhie, and A. Udayati, Kedudukan dan Tugas Hakim Menurut Undang-Undang Dasar 1945. Ubhara Press, 1998.

[3] H. Djanggih and Y. Saefudin, "Pertimbangan Hakim Pada Putusan Praperadilan: Studi Putusan Nomor: 09/PID. PRA/2016/PN. Lwk Tentang Penghentian Penyidikan Tindak Pidana Politik Uang," J. Penelit. Huk. Jure, vol. 17, no. 3, pp. 413-425, 2017.

[4] M. Ulfah, A. Safrina, and W. M. H. Susilowati, "Penghentian Penyidikan: Tinjauan Hukum Administrasi dan Hukum Acara Pidana," Mimb. Hukum-Fakultas Huk. Univ. Gadjah Mada, vol. 29, no. 1, pp. 16-30, 2017.

[5] D. C. M. Tampoli, "Penghentian Penuntutan Perkara Pidana Oleh Jaksa Berdasarkan Hukum Acara Pidana," LEX Priv., vol. 4, no. 2, 2016.

[6] P. Mahmud Marzuki, "Penelitian Hukum," Jakarta: Kencana Prenada Media, 2005.

[7] B. Ashshofa, "Metode Penelitian Hukum, Jakarta." Rineka Cipta, 2004.

[8] H. S. Salim and E. S. Nurbani, "Penerapan Teori Hukum Pada Penelitian Tesis dan Disertasi," Raja Graf. Persada, Jakarta, 2013.

[9] R. H. Soemitro, "Metodologi Penelitian Hukum dan Jurimetri," Ghalia Indones. Jakarta, vol. 167, 1990.

[10] M. Fajar and Y. Achmad, "Dualisme penelitian hukum normatif dan empiris," Yogyakarta: Pustaka Pelajar, 2010.

[11] M. B. Miles and A. M. Huberman, "Qualitative Data Analysis (terjemahan)." Jakarta: UI Press, 2007.

[12] B. P. P. KUHAP, "Departemen Kehakiman Republik Indonesia," Penerbit Yayasan Pengayoman, Cetakan ke3, Jakarta.

[13] U.-U. Nomor, "Tahun 1981 tentang Kitab Undang-Undang Hukum Acara Pidana." 8AD.

[14] M. Karjadi and S. (Raden.), Kitab UndangUndang Hukum Acara Pidana dengan penjelasan resmi dan komentar (serta Peraturan Pemerintah RI No. 27 tahun 1983 tentang pelaksanaanya). Politeia, 1988.

[15] C. S. T. Kansil, Pengantar Ilmu Hukum dan Tata Hukum Indonesia. Balai Pustaka, 1992.

[16] P. A. F. Lamintang, "Dasar-Dasar Hukum Pidana Indonesia, Bandung: PT," Citra Aditya Bakti, 1997.

[17] R. Soesilo, Pokok-pokok Hukum Pidana: Peraturan Umum dan Delik-delik Khusus. Politeia, 1979. 